\title{
Analisis Faktor-Faktor Yang Mempengaruhi Tingkat Profitabilitas Perbankan \\ (Studi Kasus Pada Aset Bank Konvensional Terbesar Di Indonesia Periode 2010 - 2015)
}

\author{
Ibram Pinondang Dalimunthe ${ }^{1}$, Nofryanti ${ }^{2}$ \\ ${ }^{1}$ Program Studi S1 Akuntansi, Universitas Pamulang, ibram.pinondang86@gmail.com \\ ${ }^{2}$ Program Studi S1 Akuntansi, Universitas Pamulang, nofryanti1905@gmail.com
}

\begin{abstract}
This study examines the factors that affect the profitability of the bank with a case study on the largest conventional bank assets in Indonesia 2010-2015. The data was then tested using a panel regression with fixed effect model. The results showed that variable Capital Adequacy Ratio (CAR) and Net Interest Margin (NIM) has a positive effect on Return On Asset, variable expenses income operating (BOPO) and Loan to Deposit Ratio (LDR) negatively effect the Return On Asset, variable allowance for impairment losses (CKPN) and Non Performing Loan gross (NPL) no effect to the Return On Asset. Based on research with panel data analysis, the authors found that there are individual effects that are fixed (fixed effect).
\end{abstract}

Keywords: Return On Assets, Capital Requirement, Allowance for Impairment Losses, Non-Performing Loans Gross, Net Interest Margin, Expenses Income Operating and Loan to Deposit Ratio.

\begin{abstract}
Abstrak: Penelitian ini mengkaji tentang faktor-faktor yang mempengaruhi profitabilitas bank dengan studi kasus pada aset bank konvensional terbesar di Indonesia periode 2010-2015. Data kemudian di uji dengan menggunakan uji regresi panel dengan model fixed effect. Hasil penelitian menunjukkan bahwa variabel Capital Adequacy Ratio (CAR) dan Net Interest Margin (NIM) berpengaruh positif terhadap Return On Asset, variabel Beban Operasional Pendapatan Operasional (BOPO) dan Loan to Deposit Ratio (LDR) berpengaruh negatif terhadap Return On Asset, variabel penyisihan kerugian penurunan nilai (CKPN) dan Non Performing Loan gross (NPL) tidak berpengaruh terhadap Return On Asset. Berdasarkan penelitian dengan panel analisis data, penulis menemukan bahwa ada efek individual yang tetap (fixed effect).
\end{abstract}

Kata Kunci: Return On Asset, Kewajiban Penyediaan Modal Minimum, Cadangan Kerugian Penurunan Nilai, Non Performing Loan Gross, Net Interest Margin, Beban Operasional Pendapatan Operasional, dan Loan to Deposit Ratio.

\section{PENDAHULUAN \\ Latar Belakang}

Persaingan dalam industri perbankan kini semakin tajam, terlebih didorong oleh perkembangan pengetahuan masyarakat yang semakin selektif dalam memilih bank, yaitu bank yang dapat memberikan pelayanan keuangan berkualitas bagi bisnis dan pribadinya. Bank terbaik adalah bank yang dapat memenuhi segala kebutuhan finansial nasabahnya, sebab perbankan sangat mengandalkan kepercayaan dari masyarakat dalam mengelola dananya.

Evaluasi terhadap kinerja bank sangat diperlukan dalam menjaga kondisi 
bank yang sehat. Evaluasi kinerja keuangan bank merupakan bagian dari kinerja bank secara keseluruhan.

Kinerja (performance) bank secara keseluruhan merupakan gambaran prestasi yang dicapai bank dalam operasionalnya, baik menyangkut aspek keuangan, pemasaran, penghimpunan dan penyaluran dana, teknologi maupun sumber daya manusia.

Kinerja keuangan bank dapat diukur dengan indikator kecukupan modal, likuiditas dan profitabilitas. Penilaian aspek penghimpunan dan penyaluran dana merupakan kinerja keuangan yang berkaitan dengan peran bank sebagai lembaga intermediasi. Sedangkan penilaian kondisi likuiditas bank berguna untuk mengetahui seberapa besar kemampuan bank dalam memenuhi kewajibannya kepada para deposan.

Bank selalu berusaha menghimpun dana sebesar-besarnya dari masyarakat. Semakin besar bank dapat menghimpun dana dari masyarakat, semakin besar kemungkinan bank tersebut dapat memberikan kredit dan ini berarti semakin besar kemungkinan bank tersebut memperoleh pendapatan bunga (interest income), sebaliknya semakin kecil dana yang dihimpun semakin kecil pula kredit yang diberikan, maka semakin kecil pula pendapatan bank. Peningkatan pendapatan dari total aktiva yang dimiliki oleh bank dapat menggambarkan kondisi bank dan kemampuan pengelolaannya.

Wijayanti (2017) mengemukakan bahwa faktor-faktor yang mempengaruhi profitabilitas bank antara lain CAR, NPL, NIM, LDR dan BOPO. Listiyani (2014) menyebutkan DPK, CAR, NPL, dan LDR adalah faktor yang mempengaruhi profitabilitas. Dewi dkk (2011) menyebutkan CAR, FDR, NPF, dan OER adalah faktor yang mempengaruhi profitabilitas bank syariah. Wibowo dan Syaichu menyebutkan bahwa suku bunga, inflasi, CAR, BOPO, NPF adalah faktor yang mempengaruhi profitabilitas bank.

\section{Rumusan Masalah}

1. Apakah terdapat pengaruh Kewajiban Penyediaan Modal Minimum (KPMM) terhadap Return On Asset (ROA)?

2. Apakah terdapat pengaruh Cadangan Kerugian Penurunan Nilai (CKPN) terhadap Return On Asset (ROA)?

3. Apakah terdapat pengaruh Non Performing Loan Gross (NPL Gross) terhadap Return On Asset (ROA)?

4. Apakah terdapat pengaruh Net Interest Margin (NIM) terhadap Return On Asset (ROA)?

5. Apakah terdapat pengaruh Beban Operasional Pendapatan Operasional (BOPO) terhadap Return On Asset (ROA)?

6. Apakah terdapat pengaruh Loan to Deposit Ratio (LDR) terhadap Return On Asset (ROA)?

7. Apakah terdapat pengaruh Kewajiban Penyediaan Modal Minimum (KPMM), Cadangan Kerugian Penurunan Nilai (CKPN), Non Performing Loan Gross (NPL Gross), Net Interest Margin (NIM), Beban Operasional Pendapatan Operasional (BOPO), dan Loan to Deposit Ratio (LDR) secara simultan terhadap Return On Asset (ROA)?

\section{Tujuan Penelitian}

Kajian ini bertujuan dari untuk mengetahui tentang analisis faktor-faktor yang mempengaruhi tingkat profitabilitas bank dengan studi kasus pada bank konvensional dengan aset terbesar di Indonesia periode 2010 - 2015.

\section{KAJIAN PUSTAKA \\ Definisi Bank}

Pengertian bank menurut Pernyataan Standar Akuntansi Keuangan (PSAK) nomor 31 tentang Akuntansi Perbankan, bank merupakan suatu lembaga yang berperan sebagai perantara keuangan (financial intermediary) antara pihakpihak yang memiliki kelebihan dana (surplus unit) dengan pihak-pihak yang memerlukan dana (deficit unit), serta sebagai lembaga yang berfungsi 
memperlancar lalu lintas pembayaran (PSAK, 1994: 1).

Kasmir (2008: 25), mengungkapkan secara lebih luas bahwa bank merupakan perusahaan yang bergerak dalam bidang keuangan, artinya aktivitas perbankan selalu berkaitan dalam bidang keuangan, sehingga berbicara mengenai bank tidak terlepas dari masalah keuangan.

Jenis Bank

Menurut Lukman Dendawijaya (2003: 26), jenis atau bentuk bank bermacam-macam, tergantung pada cara penggolongannya. Penggolongan dapat dilakukan berdasarkan hal-hal sebagai berikut:

a. Formalitas berdasarkan undang-undang

1) Bank umum;

2) Bank perkreditan rakyat.

b. Kepemilikannya

1) Bank milik negara (Badan Usaha Milik Negara atau BUMN);

2) Bank milik pemerintah daerah (Badan Usaha Milik Daerah atau BUMD);

3) Bank milik swasta nasional;

4) Bank milik swasta campuran (nasional dan asing);

5) Bank milik asing (cabang atau perwakilan).

c. Penekanan kegiatan usahanya

1) Bank retail (retail banks);

2) Bank korporasi (corporate banks);

3) Bank komersil (commercial banks);

4) Bank pembangunan (development banks);

5) Dan lain-lain.

d. Pembayaran bunga atau pembagian hasil usaha

1) Bank konvensional;

2) Bank berdasarkan prinsip syariah

e. Kasmir (2008: 20), menyebutkan fungsi bank berdasarkan status

1) Bank devisa, yaitu bank yang dapat melaksanakan ke luar negeri atau berhubungan dengan mata uang asing secara keseluruhan;

2) Bank non devisa, yaitu bank yang memperoleh izin untuk melaksanakan sebagai bank devisa, namun tidak dapat melaksanakan transaksi seperti halnya bank devisa.

\section{Laporan Keuangan}

Laporan keuangan dapat diartikan dengan data-data keuangan yang disusun secara teratur dalam suatu daftar tertentu. Untuk memperjelas pengertian laporan keuangan, di bawah ini dijelaskan oleh beberapa pendapat diantaranya:

a. S. Munawir (2004: 2), menyatakan:

Laporan keuangan pada dasarnya adalah hasil dari proses akuntansi yang dapat digunakan sebagai alat untuk berkomunikasi antara data keuangan atau aktivitas suatu perusahaan dengan pihak-pihak yang berkepentingan dengan data atau aktivitas perusahaan tersebut.

b. MP.Simangunsong

(1994:1), menyatakan: Laporan keuangan ialah laporan secara sistematis/ keadaan keuangan suatu perusahaan dan merupakan sumber informasi keuangan kepada pihak yang membutuhkan baik intern maupun extern.

c. Bambang Riyanto (1975: 181), menyatakan:

Laporan finansiil (financial statement) memberikan ikhtisar mengenai keadaan finansiil suatu perusahaan, dimana neraca (balance sheet) mencerminkan nilai aktiva, hutang dan modal sendiri pada suatu saat tertentu, dan "income statement" mencerminkan hasil-hasil yang dicapai selama suatu periode tertentu.

d. Martono dan D. Agus Harjito (2010: 51), menyatakan:

Laporan keuangan (financial statement) merupakan ihktisar mengenai keadaan keuangan suatu perusahaan pada suatu saat tertentu.

e. Abdul Halim dan Sarwoko (2008: 37), menyatakan:

Laporan keuangan merupakan kumpulan data yang diorganisasi menurut logika dan prosedur-prosedur akuntansi yang konsisten. Dari laporan keuangan diperoleh suatu pengetahuan 
tentang beberapa aspek keuangan suatu perusahaan.

\section{Kinerja Keuangan Bank \\ Capital Adequacy Ratio (CAR)}

Dendawijaya (2009:

mengatakan CAR adalah rasio yang memperlihatkan seberapa jauh seluruh aktiva bank yang mengandung risiko (kredit, penyertaan, surat berharga, tagihan pada bank lain) ikut dibiayai dari dana modal sendiri bank disamping memperoleh dana-dana dari sumbersumber di luar bank, seperti dana dari masyarakat, pinjaman, dan lain-lain. CAR merupakan indikator terhadap kemampuan bank untuk menutupi penurunan aktivanya sebagai akibat dari kerugian-kerugian bank yang disebabkan oleh aktiva yang berisiko.

Setiap bank yang beroperasi di Indonesia diwajibkan untuk memelihara Kewajiban Penyediaan Modal Minimum (KPMM) sekurang-kurangnya $\quad 8 \%$. Minimum CAR sebesar $8 \%$ ini, dari waktu ke waktu akan disesuaikan dengan kondisi dan perkembangan perbankan yang terjadi, dengan tetap mengacu pada standar internasional, yaitu Banking for International Settlement (BIS) yang berpusat di Geneva (Slamet Riyadi, 2003: 186).

\section{Cadangan Kerugian Penurunan Nilai (CKPN)}

Kerugian penurunan nilai terjadi pada saat kelompok aset keuangan diturunkan nilainya. Jika terjadi bukti objektif dari penurunan nilai tersebut akibat dari satu atau lebih peristiwa setelah pengakuan awal dan peristiwa yang merugikan tersebut berdampak pada arus kas masa depan maka perusahaan sudah mengalami penurunan nilai pada kelompok aset keuangannya. Pada dasarnya penurunan nilai suatu perusahaan sulit di identifikasi dan jika terjadi merupakan dampak dari kombinasi beberapa peristiwa. Menurut PSAK 55 paragraf 66 terdapat 6 peristiwa yang menyebabkan penurunan nilai diantaranya: a. Kesulitan keuangan signifikan yang dialami penerbit atau pihak peminjam;

b. Pelanggaran kontrak, seperti terjadinya wanprestasi atau tunggakan pembayaran pokok atau bunga;

c. Pihak pemberi pinjaman, dengan alasan ekonomi atau hukum sehubungan dengan kesulitan keuangan yang dialami pihak peminjam, memberikan keringanan (konsesi) pada pihak peminjam yang tidak mungkin diberikan jika pihak peminjam tidak mengalami kesulitan tersebut;

d. Terdapat kemungkinan bahwa pihak peminjam akan dinyatakan pailit atau melakukan reorganisasi keuangan lainnya;

e. Hilangnya pasar aktif dari aset keuangan akibat kesulitan keuangan;

f. Data yang dapat di observasi mengindikasikan adanya penurunan yang dapat diukur atas estimasi arus kas masa depan dari kelompok aset keuangan sejak pengakuan awal aset dimaksud. Termasuk memburuknya status pembayaran pihak peminjam dan kondisi ekonomi nasional atau lokal yang berkorelasi dengan wanprestasi atas aset dalam kelompok tersebut.

Adapun ketentuan pengukuran cadangan menurut LLP/ CKPN berdasarkan PAPI (Pedoman Akuntansi Perbankan Indonesia) Revisi 2008 dibagi menjadi:

g. Individual Setiap bank dapat memilih perhitungan untuk mengukur nilai CKPN Individual dengan menggunakan metode seperti di bawah ini:

1) Discounted Cash Flow: Estimasi arus kas masa akan datang (pembayaran pokok + bunga) yang di diskonto dengan suku bunga.

2) Fair Value of Collateral: Dengan memperhitungkan nilai arus kas atas jaminan atau agunan di masa yang akan datang.

3) Observable Market Price: Ditentukan dari harga pasar dari kredit tersebut. 
h. Kolektif Setiap bank dapat memilih beberapa ketentuan dalam menentukan nilai CKPN pada kelompok kolektif ini sebagai berikut:

1) Dilihat dari perhitungan arus kas kontraktual kreditur di masa akan datang.

2) Dilihat dari perhitungan tingkat kerugian historis dari kredit debitur setelah dikurangi tingkat pengembalian kreditnya.

\section{Non Performing Loan (NPL)}

NPL adalah risiko kredit bermasalah dengan total kredit. NPL yang baik adalah NPL yang memiliki nilai dibawah 5\%. NPL mencerminkan risiko kredit, semakin kecil NPL semakin kecil pula risiko kredit yang ditanggung bank. Bank dengan NPL yang tinggi akan memperbesar biaya baik pencadangan aktiva produkif maupun biaya lainnya, sehingga berpotensi terhadap kerugian bank (Wisnu Mawardi, 2005).

Terhadap kredit yang mengarah menjadi NPL bahkan kredit NPL sendiri dapat diterapkan beberapa teknik penyehatan agar debitur dapat bangkit kembali (Z. Dunil, 2005):

\section{a. Rescheduling}

Bank dapat melakukan penjadwalan ulang dalam bentuk perpanjangan masa pelunasan, memberikan grace period yang lebih panjang, memperkecil jumlah angsuran kredit. Dengan penjadwalan ini nasabah lebih mempunyai waktu untuk bernafas dan jangka waktu cukup untuk akumulasi keuntungan dan memperbaiki posisinya sehingga dapat memenuhi jadwal baru yang ditetapkan. Penjadwalan ulang ini dilakukkan dengan persyaratan tertentu antara lain, usaha nasabah masih berjalan, pendapatan sebelum pembebanan bunga masih positif. Ketidakmampuan nasabah melaksanakan pelunasan semata-mata karena situasi yang diluar kontrol (kewenangan) debitur yang bersangkutan. Nasabah masih beritikad baik dan koperatif.

\section{b. Reconditioning}

Reconditioning dimaksudkan untuk memperbaiki kondisi nasabah, yang semula terbebani dengan persyaratan kredit yang berat, dikurangi sehingga lebih pas bagi kebutuhan nasabah. Mengurangi tingkat bunga, mengurangi kredit dari pihak lain yang bunganya tinggi dan menggantinya dengan kredit dari bank dengan bunga lebih rendah, menambah modal kerja bila menurut perhitungan bank memang ternyata kurang. Memberikan konsultasi manajemen atau advis perusahaan dapat berjalan lebih baik dan mampu meningkatkan penjualan, laba dan mampu menyelesaikan kreditnya dalam jangka waktu yang ditetapkan.

c. Restructuring

Apabila kedua cara di atas diperkirakan tidak akan dapat menyehatkan kembali perusahaan dan tidak akan dapat mengembalikan kredit bank, maka dapat ditempuh cara terakhir dengan merestrukturisasi perusahaan secara lebih mendasar. Dalam hal ini dapat dilakukan perubahan komposisi permodalan, dengan memperbaiki debt to equity ratio, dengan menambah modal (partisipasi bank maupun dari luar), menambah kredit, memperpanjang jangka waktu, memperkecil tingkat bunga, mengganti manajemen (menempatkan staf bank pada perusahaan untuk posisi tertentu) meningkatkan efisiensi dan sebagainya. Langkah partisipasi modal dimaksudkan agar debitur tidak perlu membayar bunga terhadap sebagian hutang yang dialihkan menjadi pernyataan modal bank. Setelah perusahaan sehat dan kemampuan keuangannya lebih baik, bank dapat menjual kembali saham yang dikuasainya kepada pemegang saham lama dengan premium tertentu. Dengan 
demikian, apabila berhasil bank terhindar dari kemacetan kredit.

\section{Net Interest Margin (NIM)}

Net Interest Margin (NIM) adalah rasio untuk mengukur keuntungan bersih yang diperoleh bank dari pendapatan yang diterima dari kegiatan operasionalnya. Dengan kata lain Net Interest Margin (NIM) dapat diartikan sebagai selisih antara pendapatan bunga dengan biaya bunga sebagai bagian atau proporsi dari total aset atau aktiva produktif bank.

Net Interest Margin (NIM) penting untuk mengevaluasi kemampuan bank dalam mengelola risiko terhadap suku bunga. Saat suku bunga berubah, pendapatan bunga dan biaya bunga akan berubah. Sebagai contoh saat suku bunga naik, baik pendapatan bunga maupun biaya bunga akan naik karena beberapa aset dan liabilitas bank akan dihargai pada tingkat yang lebih tinggi (Koch dan Scott, 2000).

Fungacova (2008) menyatakan bahwa ada beberapa faktor yang mempengaruhi NIM:

a. Struktur persaingan dari produk perbankan

Pada intinya, tingkat persaingan tercermin dari koefisien alpha dan beta untuk pasar deposit dan loan. Makin kompetitif kedua pasar tersebut, secara konsep maka besaran Net Interest Margin (NIM) akan semakin kecil dan sebaliknya. Hal ini terjadi karena dalam pasar yang kompetitif, tidak ada peluang bagi pelaku usaha (bank) untuk menetapkan excessive margin atau melakukan abuse of market power.

b. Rata-rata biaya operasional

Secara teori, bank harus tetap mempertahankan marjin positif untuk menutup biaya operasionalnya. Makin tinggi biaya operasional, makin tinggi tingkat Net Interest margin (NIM) yang harus ditetapkan oleh bank. Sebaliknya, apabila bank dapat meningkatkan efisiensi operasionalnya, maka spread atau marjin dapat juga ditekan atau dikurangi.

c. Risk Averse

Perbankan diasumsikan memiliki sikap risk averse. Dalam kondisi risk averse, makin tinggi risiko yang dihadapi oleh bank, maka kompensasi marjin terhadap risiko tersebut juga akan makin besar, begitu juga dengan kondisi sebaliknya.

d. Volatilitas suku bunga pasar uang Pada prinsipnya, makin tinggi tingkat volatilitas suku bunga pasar uang, maka makin tinggi pula tingkat risiko dan premi yang harus dihadapi oleh perbankan. Dengan demikian, makin besar pula tingkat Net Interest Margin (NIM) yang harus ditetapkan oleh perbankan, begitu juga dengan kondisi sebaliknya.

e. Tingkat risiko kredit

Hampir sama dengan prinsip pengaruh volatilitas suku bunga pasar uang, makin tinggi tingkat risiko kredit yang dihadapi oleh perbankan, makin tinggi pula tingkat premi risiko yang harus diemban sehingga Net Interest Margin (NIM) akan semakin besar, begitu juga dengan kondisi sebaliknya.

f. Volume atau nilai dari kredit dan deposit

Pada intinya, makin besar jumlah kredit yang diberikan dan deposit yang dikumpulkan oleh bank, maka makin besar pula tingkat potensial loss yang dihadapi oleh bank, sehingga perlu di kompensasi dengan tingkat Net Interest Margin (NIM) yang besar pula. Namun, daari perspektif skala ekonomis, makin besar penyaluran kredit maka seharusnya terdapat benefit efisiensi yang ditimbulkan terkait dengan biaya per unit untuk pengelolaan dan penyaluran portofolio kredit.

\section{Beban Operasional Pendapatan Operasional (BOPO)}

Rasio BOPO adalah rasio yang mengukur tingkat efisiensi dan efektivitas operasional suatu perusahaan dengan 
membandingkan beban operasional terhadap pendapatan operasional (Dendawijaya, 2009: 119).

Biaya operasional adalah semua biaya yang berhubungan langsung dengan kegiatan usaha bank (Dendawijaya, 2009: 111). Sedangkan pendapatan operasional terdiri atas semua pendapatan yang merupakan hasil langsung dari kegiatan usaha bank yang benar-benar diterima.

Mengingat kegiatan utama bank adalah menghimpun dan menyalurkannya kembali kepada masyarakat, maka biaya dan pendapatan yang mendominasi pada bank adalah biaya bunga dan hasil bunga. Hal yang terpenting untuk mencapai keefisiensian operasional adalah meningkatkan produktivitas perusahaan, menekan biaya, sehingga menghasilkan output yang maksimal dan akan mempengaruhi laba (Koch, 2003: 112).

Bank Indonesia menetapkan angka terbaik untuk rasio BOPO adalah dibawah 90\%, karena jika rasio BOPO melebihi 90\% hingga mendekati 100\% maka bank tersebut dapat dikategorikan tidak efisien dalam menjalankan kegiatan operasionalnya.

\section{Loan to Deposit Ratio (LDR)}

Loan to Deposit Ratio (LDR) adalah rasio kredit yang diberikan kepada pihak ketiga dalam rupiah dan valuta asing, tidak termasuk kredit kepada bank lain, terhadap Dana Pihak Ketiga (DPK) yang mencakup giro, tabungan, dan deposito dalam rupiah dan valuta asing, tidak termasuk dana antar bank (SEBI No.15/41/DKMP).

Menurut Lukman Dendawijaya (2009), Loan to Deposit Ratio (LDR) menyatakan seberapa jauh kemampuan bank dalam membayar kembali penarikan dana yang dilakukan deposan dengan mengandalkan kredit yang diberikan sebagai sumber likuiditasnya. Jika bank dapat menyalurkan seluruh dana yang dihimpun memang akan menguntungkan, namun hal ini terkait risiko apabila sewaktu-waktu pemilik dana menarik dananya atau pemakai dana tidak dapat mengembalikan dana yang dipinjamnya. Sebaliknya, apabila bank tidak menyalurkan dananya maka bank juga akan terkena risiko karena hilangnya kesempatan untuk memperoleh keuntungan, batas minimum pinjaman yang diberikan bank adalah $80 \%$ dan maksimum $110 \%$.

\section{Return On Asset (ROA)}

Tujuan dari analisis profitabilitas suatu bank adalah untuk mengukur tingkat efisiensi usaha dan profitabilitas yang dicapai oleh bank yang bersangkutan (Kuncoro, 2001). Kinerja keuangan perusahaan dari sisi manajemen, mengharapkan laba bersih sebelum pajak (earning before tax) yang tinggi karena semakin tinggi laba perusahaan semakin flexible perusahaan dalam menjalankan aktivitas operasional perusahaan. Sehingga EBT perusahaan akan meningkat bila kinerja keuangan perusahaan meningkat. Laba sebelum pajak adalah laba bersih dari kegiatan operasional sebelum pajak. Sedangkan rata-rata total aset merupakan rata-rata volume usaha atau aktiva (Dendawijaya, 2009).

Penggunaan Return On Asset (ROA) lebih diutamakan dari Return On Equity (ROE), karena ROA terfokus pada kemampuan perusahaan untuk memperoleh earning dalam kegiatan operasional bank. Selain itu, dalam penentuan tingkat kesehatan suatu bank, Bank Indonesia lebih mementingkan penilaian besarnya Return On Asset (ROA) dan tidak memasukkan unsur Return On Equity (ROE). Menurut Dendawijaya (2009: 119), Bank Indonesia sebagai pembina dan pengawas perbankan lebih mengutamakan nilai profitabilitas suatu bank yang diukur dengan aset yang dananya sebagian besar dari dana simpanan masyarakat.

Gitman (2003: 65) mengatakan bahwa return on total assets (ROA) measures the overall effectiveness of management in generating profits with its 
available assets; also called the return on investment (ROI).

Dendawijaya

(2009:

menjelaskan bahwa rasio ROA digunakan untuk mengukur kemampuan manajemen bank dalam memperoleh keuntungan (laba) secara keseluruhan, semakin besar ROA semakin besar pula tingkat keuntungan yang dicapai bank tersebut dan semakin besar pula posisi bank dari segi penggunaan aset.

Return On Asset (ROA) merupakan salah satu rasio profitabilitas yang digunakan untuk mengukur efektivitas perusahaan dalam menghasilkan keuntungan dengan memanfaatkan total yang dimilikinya. Berdasarkan ketentuan Bank Indonesia, maka standar ROA yang baik adalah sekitar $1,5 \%$. Semakin besar ROA menunjukkan kinerja perusahaan semakin baik, karena return semakin besar.

\section{METODOLOGI PENELITIAN Penentuan Sampel}

Teknik pengambilan sampel dalam penelitian ini menggunakan puposive sampling yaitu didasarkan pada suatu pertimbangan tertentu yang dibuat oleh peneliti sendiri, berdasarkan ciri atau sifatsifat populasi yang sudah diketahui sebelumnya (Sumanto, 2014: 169).

Adapun metode purposive sampling yang peneliti lakukan yaitu dengan cara mengklasifikasikan perbankan berdasarkan kategori dan aset terbesar.

1. Bank yang terdaftar di Indonesia.

2. Bank berdasarkan klasifikasi kepemilikan.

3. 2 bank dengan jumlah aset terbesar.

Tabel 1. Klasifikasi perbankan berdasarkan kategori dan aset terbesar periode 2015 (dalam jutaan rupiah)

\begin{tabular}{|c|c|c|c|}
\hline No & Kategori & Nama Bank & Total Aset \\
\hline 1. & Bank Persero & $\begin{array}{l}\text { - PT Bank Mandiri (Persero), Tbk } \\
\text { - PT Bank Rakyat Indonesia (Persero), Tbk }\end{array}$ & $\begin{array}{l}\text { - } 910.063 .409 \\
\text { - } 878.426 .312\end{array}$ \\
\hline 2. & $\begin{array}{l}\text { Bank Umum Swasta } \\
\text { Nasional Devisa }\end{array}$ & $\begin{array}{l}\text { - PT Bank Central Asia, Tbk } \\
\text { - } \text { PT Bank CIMB Niaga, Tbk - UUS }\end{array}$ & $\begin{array}{l}\text { - } 594.372 .770 \\
\text { - } 238.849 .252\end{array}$ \\
\hline 3. & $\begin{array}{l}\text { Bank Umum Swasta } \\
\text { Nasional Non Devisa }\end{array}$ & $\begin{array}{l}\text { - PT Bank Bukopin, Tbk } \\
\text { - PT Bank Tabungan Pensiunan Nasional, Tbk }\end{array}$ & $\begin{array}{l}\text { - } 94.366 .502 \\
\text { - } \quad 81.039 .663\end{array}$ \\
\hline 4. & Bank Campuran & $\begin{array}{l}\text { - } \text { PT Bank DBS Indonesia } \\
\text { - PT Bank ANZ Indonesia }\end{array}$ & $\begin{array}{l}\text { - } \quad 62.816 .433 \\
\text { - } 42.292 .269\end{array}$ \\
\hline 5. & Bank Asing & $\begin{array}{l}\text { - The Bank Of Tokyo Mitsubishi UFJ Ltd } \\
\text { - The Hongkong and Shanghai Banking Corp }\end{array}$ & $\begin{array}{r}\text { - } 138.171 .000 \\
\text { - } 92.454 .590\end{array}$ \\
\hline 6. & $\begin{array}{l}\text { Bank Pembangunan } \\
\text { Daerah }\end{array}$ & $\begin{array}{l}\text { - PT BPD Jawa Barat dan Banten, Tbk } \\
\text { - PT BPD Jawa Timur - UUS }\end{array}$ & $\begin{array}{l}\text { - } \quad 88.697 .430 \\
\text { - } 42.803 .631\end{array}$ \\
\hline
\end{tabular}

*Otoritas Jasa Keuangan - data diolah

\section{Metode Pengumpulan Data}

Metode pengumpulan data penelitian yang digunakan adalah penelitian kepustakaan (library research).

Penelitian kepustakaan yaitu dengan menelaah data, buku, literatur dan laporan, serta peraturan perundang-undangan yang ada hubungannya dengan masalah yang diteliti serta dengan mengakses situs resmi Bank Indonesia (www.bi.go.id), dan Otoritas Jasa Keuangan (www.ojk.go.id) serta dokumen berupa laporan keuangan yang dikeluarkan oleh bank yang diteliti dalam Laporan Publikasi Triwulan periode tahun 2010 hingga 2015.

Penelitian ini bertujuan untuk mengetahui faktor-faktor yang mempengaruhi tingkat profitabilitas perbankan (studi kasus pada aset bank konvensional terbesar di Indonesia periode 2010 - 2015). Berdasarkan sifat permasalahannya, maka penelitian ini lebih sesuai di analisis dengan menggunakan pendekatan kuantitatif 
dengan metode deskriptif analitik yang menggunakan pendekatan analisis korelasi dan regresi yang semua proses penghitungannya menggunakan alat bantu komputer serial EViews versi 7.2 for Windows.

\section{Tahapan Analisis Data}

Untuk memilih model yang paling tepat digunakan dalam mengelola data panel, terdapat beberapa pengujian yang dapat dilakukan, diantaranya uji Chow dan uji Hausman.

Uji dasar asumsi klasik dilakukan sebagai parameter untuk mengukur apakah data yang digunakan dalam penelitian ini bersifat BLUE (Best Linier Unbiased Estimator) atau tidak yang diantaranya uji Normalitas, uji Multikolinearitas, uji Heteroskedastisitas, dan uji autokorelasi.

Koefisien determinasi $\left(\mathrm{R}^{2}\right)$ digunakan untuk mengukur seberapa baik garis regresi sesuai dengan data aktualnya (goodness of fit). Koefisien determinasi ini mengukur persentase total varian variabel dependen Y yang dijelaskan oleh variabel independen di dalam garis regresi. Menurut Sulaiman (2004: 86) nilai $\mathrm{R}^{2}$ mempunyai interval antara 0 sampai $1(0<$ $\left.\mathrm{R}^{2}<1\right)$. Semakin besar $\mathrm{R}^{2}$ (mendekati 1$)$, semakin baik hasil untuk model regresi tersebut dan semakin mendekati 0 maka variabel independen secara keseluruhan tidak dapat menjelaskan variabel dependen.

Menurut Suliyanto (2011: 40), uji F digunakan untuk menguji pengaruh secara simultan variabel bebas terhadap variabel tergantungnya. Jika variabel bebas memiliki pengaruh secara simultan terhadap variabel tergantung, maka model persamaan regresi masuk dalam kriteria cocok atau fit.

Sementara uji $\mathrm{t}$ digunakan untuk melihat signifikansi dari pengaruh independen secara individu terhadap variabel dependen dengan menganggap variabel lain bersifat konstan. Nilai thitung digunakan untuk menguji apakah sebuah variabel bebas berpengaruh secara signifikan terhadap variabel tergantung atau tidak.

\section{HASIL PENELITIAN DAN ANALISIS Uji Normalitas}

Berikut adalah hasil dari uji normalitas data yang digunakan dalam penelitian ini:

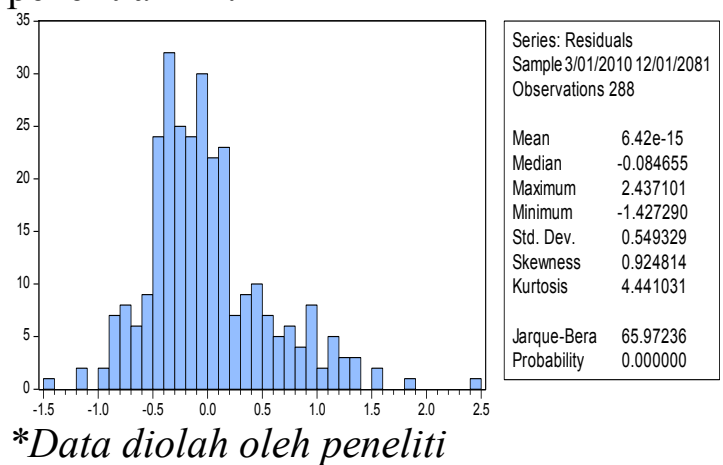

Gambar 1. Uji Normalitas

Dari grafik histogram diatas dapat dilihat bahwa nilai Jarque-Bera sebesar 65,97236 atau berada diatas nilai $X^{2}$ tabel yaitu sebesar 11,07050. Selain itu nilai probabilitasnya sebesar 0,000000, nilai tersebut lebih kecil dari derajat kesalahan yaitu 5\% atau 0,05. Maka dapat disimpulkan bahwa data dalam penelitian ini berdistribusi normal.

\section{Uji Multikolinearitas}

Pada penelitian ini, ada atau tidaknya multikolinearitas dapat diketahui atau dilihat dari koefisien korelasi masingmasing variabel bebas. Jika koefisien korelasi diantara masing-masing variabel bebas lebih besar dari 0,80 maka terjadi multikolinearitas. Berikut ini adalah hasil uji multikolinearitas:

Tabel 2. Uji Multikolinearitas

\begin{tabular}{ccccccc} 
& KPMM & CKPN & NPLGROSS & NIM & BOPO & LDR \\
\hline \hline KPMM & 1.000000 & -0.475665 & -0.228159 & -0.164864 & -0.049262 & 0.703696 \\
CKPN & -0.475665 & 1.000000 & 0.579598 & 0.218288 & 0.053114 & -0.324171 \\
NPLGROSS & -0.228159 & 0.579598 & 1.000000 & -0.133723 & 0.316405 & -0.175870 \\
NIM & -0.164864 & 0.218288 & -0.133723 & 1.000000 & -0.197896 & -0.375843 \\
BOPO & -0.049262 & 0.053114 & 0.316405 & -0.197896 & 1.000000 & -0.016397 \\
LDR & 0.703696 & -0.324171 & -0.175870 & -0.375843 & -0.016397 & 1.000000 \\
* Data & diolah oleh peneliti & & &
\end{tabular}

Dari tabel diatas dapat dilihat bahwa nilai koefisien korelasi antar variabel independen dalam penelitian ini berada 
pada kisaran antara -0.475665 hingga 0.703696 yang berarti masih di bawah 0,80 sehingga dapat disimpulkan bahwa data yang digunakan dalam penelitian ini terbebas dari masalah multikolinearitas.

\section{Uji Heteroskedastisitas}

Berikut ini adalah hasil uji White yang dilakukan terhadap data yang digunakan dalam penelitian ini:

Tabel 3. Uji Heteroskedastisitas

Heteroskedasticity Test: White

\begin{tabular}{llll}
\hline \hline & & & \\
F-statistic & 4.764211 & Prob. F(27,260) & 0.0000 \\
Obs*R-squared & $\mathbf{9 5 . 3 2 4 9 9}$ & Prob. Chi-Square(27) & $\mathbf{0 . 0 0 0 0}$ \\
Scaled explained SS & 156.1324 & Prob. Chi-Square(27) & 0.0000 \\
* Data diolah & oleh peneliti &
\end{tabular}

Dari tampilan tabel diatas, dapat dilihat bahwa nilai probabilitas berada dibawah 0,05. Dengan demikian, maka dalam penelitian ini tidak ditemukannya masalah heteroskedastisitas.

\section{Uji Autokorelasi}

Uji autokorelasi dimaksudkan untuk mengetahui apakah ada korelasi antara anggota serangkaian data observasi yang diuraikan menurut waktu atau ruang (Suliyanto, 2011: 125). Uji autokorelasi dalam penelitian ini dilakukan dengan metode Durbin-Watson (DW).

Tabel 4. Hasil Uji Autokorelasi

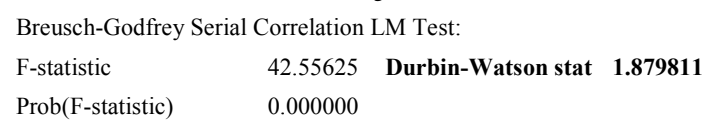

Dari tabel diatas, dapat dilihat bahwa nilai DW adalah sebesar 1,879811 dari model regresi yang terbentuk dari penelitian ini berada pada daerah bebas autokorelasi sehingga dapat disimpulkan bahwa data yang digunakan dalam penelitian ini terbebas dari masalah autokorelasi.

Tabel 5. Koefisien determinasi

$\begin{array}{lrll}\text { R-squared } & 0.876379 & \text { Mean dependent var } & 3.038396 \\ \text { Adjusted R-squared } & 0.868596 & \text { S.D. dependent var } & 1.213455 \\ \text { S.E. of regression } & 0.439874 & \text { Akaike info criterion } & 1.255806 \\ \text { Sum squared resid } & 52.24213 & \text { Schwarz criterion } & 1.484741 \\ \text { Log likelihood } & -162.8360 & \text { Hannan-Quinn criter. } & 1.347549 \\ \text { F-statistic } & 112.5939 & \text { Durbin-Watson stat } & 0.860094 \\ \text { Prob(F-statistic) } & 0.000000 & & \end{array}$

Dari Tabel 4 model fixed effect dapat dilihat bahwa nilai Adjusted $R$-Square dari model regresi yang terbentuk dalam penelitian ini adalah sebesar 0,868596 yang menunjukkan bahwa kemampuan variabel independen [Kewajiban Penyediaan Modal Minimum (KPMM), Cadangan Kerugian Penurunan Nilai (CKPN), Non Performing Loan Gross (NPL) Gross, Net Interest Margin (NIM), Beban Operasional Pendapatan Operasional (BOPO), dan Loan to Deposit Ratio (LDR)] dalam menjelaskan variabel dependen (Return On Asset) adalah sebesar 86,8596\%, sisanya sebesar $13,1404 \%$ dijelaskan oleh variabel lain yang tidak termasuk dalam model ini.

\section{Uji F}

Dalam penelitian ini, uji F dilakukan untuk mengetahui pengaruh variabel independen [Kewajiban Penyediaan Modal Minimum (KPMM), Cadangan Kerugian Penurunan Nilai (CKPN), Non Performing Loan Gross (NPL) Gross, Net Interest Margin (NIM), Beban Operasional Pendapatan Operasional (BOPO), dan Loan to Deposit Ratio (LDR)] berpengaruh terhadap variabel dependen (Return On Asset (ROA)) Jika nilai F Fitung $>$ dari $\mathrm{F}_{\text {tabel, bahwa variabel independen }}$ secara berpengaruh secara signifikan terhadap variabel dependen, tetapi jika $\mathrm{F}_{\text {hitung }}<\mathrm{F}_{\text {tabel }}$, bahwa variabel independen secara tidak berpengaruh terhadap variabel dependen.

Dari Tabel 3 model fixed effect, dapat dilihat bahwa nilai $F_{\text {hitung }}$ adalah 112,5939 dengan probabilitas 0,000000 . Sementara nilai $\mathrm{F}_{\text {tabel }}$ dengan df: $\alpha,(\mathrm{k}-1),(\mathrm{n}-$ k) atau 0,05, (6-1), (288-6) adalah 1,83 yang berarti lebih kecil dari $\mathrm{F}_{\text {hitung }}$ maka

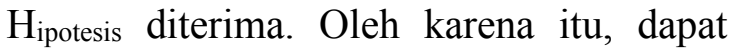
disimpulkan bahwa variabel independen [Kewajiban Penyediaan Modal Minimum (KPMM), Cadangan Kerugian Penurunan Nilai (CKPN), Non Performing Loan Gross (NPL) Gross, Net Interest Margin (NIM), Beban Operasional Pendapatan Operasional (BOPO), dan Loan to Deposit 
Ratio (LDR)] secaraberpengaruh signifikan terhadap Return On Asset (ROA).

\section{Uji Parsial}

Uji $t$ digunakan untuk melihat signifikansi dari pengaruh independen secara individu terhadap dependen dengan menganggap variabel lain bersifat konstan. Uji ini dilakukan dengan memperbandingkan $t_{\text {hitung }}$ dengan $t_{\text {tabel. }}$. Jika $t_{\text {hitung }}>\mathrm{t}_{\text {tabel }}$, berarti $\mathrm{H}_{\text {ipoteis }}$ diterima yang berarti bahwa variabel $X i$ berpengaruh signifikan terhadap variabel dependen, tetapi jika $t_{\text {hitung }}<t_{\text {tabel}}$, maka $\mathrm{H}_{\text {ipotesis }}$ ditolak yang berarti bahwa variabel $X i$ tidak berpengaruh signifikan terhadap variabel dependen.

Tabel 6. Uji Parsial (Uji t)

Dependent Variable: ROA?

Method: Pooled Least Squares

Total pool (balanced) observations: 288

\begin{tabular}{ccccc}
\hline \hline Variable & Coefficient & Std. Error & t-Statistic & Prob. \\
\hline \hline & & & & \\
KPMM? & 0.026551 & 0.010743 & 2.471499 & 0.0141 \\
CKPN? & -0.102066 & 0.079512 & -1.283655 & 0.2004 \\
NPLGROSS? & -0.082995 & 0.045668 & -1.817346 & 0.0703 \\
NIM? & 0.189836 & 0.041001 & 4.630016 & 0.0000 \\
BOPO? & -0.090503 & 0.005004 & -18.08774 & 0.0000 \\
LDR? & -0.009958 & 0.001386 & -7.187183 & 0.0000 \\
C & 9.572464 & 0.493687 & 19.38974 & 0.0000 \\
* Data diolah oleh & peneliti & & \\
& & & &
\end{tabular}

Uji Parsial Variabel Kewajiban Penyediaan Modal Minimum (KPMM) Terhadap Variabel Return On Asset.

Dengan melihat nilai thitung (tstatistik) Kewajiban Penyediaan Modal Minimum (KPMM) sebesar 2.471499 dengan probabilitas sebesar 0,0141 lebih kecil dari nilai $\alpha=0,05$, maka dapat disimpulkan $\mathrm{H}_{2}$ diterima yang berarti bahwa variabel Kewajiban Penyediaan Modal Minimum (KPMM) berpengaruh signifikan dan positif terhadap Return On Asset
Uji Parsial Variabel Cadangan Kerugian Penurunan Nilai (CKPN) Terhadap Variabel Return On Asset.

Dengan melihat nilai thitung (tstatistik) Cadangan Kerugian Penurunan Nilai (CKPN) sebesar -1.283655 dengan probabilitas sebesar 0.2004 lebih besar dari nilai $\alpha=0,05$, maka dapat disimpulkan bahwa $\mathrm{H}_{2}$ ditolak berarti bahwa variabel Cadangan Kerugian Penurunan Nilai (CKPN) tidak berpengaruh terhadap Return On Asset

Uji Parsial Variabel Non Performing Loan Gross (NPL) Gross Terhadap Variabel Return On Asset.

Dengan melihat $t_{\text {hitung }}$ (t-statistik) Non Performing Loan Gross (NPL) Gross sebesar -1.817346 dengan probabilitas 0.0703 lebih besar dari nilai $\alpha=0,05$, maka dapat disimpulkan bahwa $\mathrm{H}_{3}$ ditolak yang berarti bahwa variabel Non Performing Loan Gross (NPL) Gross tidak berpengaruh signifikan dan negatif terhadap Return On Asset.

\section{Uji parsial variabel Net Interest Margin (NIM) terhadap Return On Asset.}

Dengan melihat thitung (t-statistik) Net Interest Margin (NIM) sebesar 4.630016 dengan probabilitas 0,0000 lebih kecil dari nilai $\alpha=0,05$, maka dapat disimpulkan bahwa $\mathrm{H}_{4}$ diterima yang berarti bahwa variabel Net Interest Margin (NIM) berpengaruh signifikan dan positif terhadap Return On Asset.

\section{Uji Parsial Variabel Beban Operasional Pendapatan Operasional (BOPO) Terhadap Variabel Return On Asset. \\ Dengan melihat $t_{\text {hitung }}$ (t-statistik)} Beban Operasional Pendapatan Operasional (BOPO) sebesar -18.08774 dengan probabilitas 0,0000 lebih kecil dari nilai $\alpha=0,05$, maka dapat disimpulkan $\mathrm{H}_{5}$ diterima yang berarti bahwa variabel Beban Operasional Pendapatan Operasional (BOPO) berpengaruh signifikan dan negatif terhadap Return On Asset. 
Uji Parsial Variabel Loan to Deposit Ratio (LDR) Terhadap Variabel Return On Asset.

Dengan melihat $t_{\text {hitung }}$ (t-statistik) Loan to Deposit Ratio (LDR) sebesar 7.187183 dengan probabilitas 0,0000 lebih kecil dari nilai $\alpha=0,05$, maka dapat disimpulkan bahwa $\mathrm{H}_{5}$ diterima yang berarti bahwa variabel Loan to Deposit Ratio (LDR) berpengaruh signifikan dan negatif terhadap Return On Asset.

\section{Analisis Regresi Panel}

Berdasarkan penjelasan diatas, maka hasil persamaan regresi panel yang bertujuan untuk menguji analisis faktorfaktor yang mempengaruhi tingkat profitabilitas perbankan (studi kasus pada aset bank konvensional terbesar di Indonesia periode 2010 - 2015).

Tabel 7. Uji Regresi Panel dengan Fixed Effect

\begin{tabular}{cccccc} 
Variable & \multicolumn{2}{c}{ Coefficient } & Std. Error & t-Statistic & Prob. \\
\hline \hline KPMM? & 0.026551 & 0.010743 & 2.471499 & 0.0141 \\
CKPN? & -0.102066 & 0.079512 & -1.283655 & 0.2004 \\
NPLGROSS? & -0.082995 & 0.045668 & -1.817346 & 0.0703 \\
NIM? & 0.189836 & 0.041001 & 4.630016 & 0.0000 \\
BOPO? & -0.090503 & 0.005004 & -18.08774 & 0.0000 \\
LDR? & -0.009958 & 0.001386 & -7.187183 & 0.0000 \\
C & 9.572464 & 0.493687 & 19.38974 & 0.0000 \\
Fixed Effects & & & & \\
(Cross) & & & & \\
BOT-C & 1.306268 & & & \\
HSBC-C & 0.657928 & & & \\
DBS-C & -0.112608 & & & \\
ANZ-C & 0.798908 & & & \\
MANDIRI-C & -0.432844 & & & \\
BRI-C & 0.197314 & & & \\
JATIM-C & -0.302067 & & & \\
BJB-C & -0.473691 & & & \\
BCA-C & -0.842971 & & & \\
CIMB-C & -0.126431 & & & \\
BUKOPIN-C & -0.345936 & & & \\
BTPN-C & -0.323869 & & & \\
& & & &
\end{tabular}

Dari hasil pengujian hipotesis, maka dapat diinterprestasikan bahwa 4 variabel yang digunakan memiliki pengaruh signifikan terhadap variabel dependen (Return On Asset), yaitu Kewajiban Penyediaan Modal Minimum, Net Interest Margin, Beban Operasional Pendapatan Operasional, dan Loan to Deposit Ratio. Sedangkan variabel Cadangan Kerugian
Penurunan Nilai dan Net Performing Loan Gross tidak berpengaruh signifikan terhadap variabel Return On Asset.

$\begin{aligned} \text { ROA } & =9.572464+0.026551 K P M M-0.102066 C K P N \\ - & \text { 0.082995NPLGross }+0.189836 N I M- \\ & \text { 0.090503BOPO - 0.009958LDR }+\mathrm{e}\end{aligned}$

SIMPULAN

a. Hasil pengujian

Hasil pengujian uji $\mathrm{F}$ menunjukkan bahwa seluruh variabel independen berpengaruh signifikan terhadap Return On Asset. Sementara dalam Uji t menunjukan bahwa variabel Kewajiban Penyediaan Modal Minimum (KPMM) berpengaruh signifikan dan positif terhadap Return On Asset, variabel Cadangan Kerugian Penurunan Nilai (CKPN) dan Non Performing Loan Gross (NPL) tidak berpengaruh terhadap Return On Asset, variabel Net Interest Margin (NIM) berpengaruh signifikan dan positif terhadap Return On Asset, variabel Beban Operasional Pendapatan Operasional (BOPO) berpengaruh signifikan dan negatif terhadap Return On Asset, dan variabel Loan to Deposit Ratio (LDR) berpengaruh signifikan dan negatif terhadap Return On Asset.

Secara parsial untuk masingmasing bank, setiap variabel independen memiliki efek terhadap variabel dependen dengan konstanta yang berbeda-beda.

b. Nilai adjusted R-Square

Nilai Adjusted R-Square dari model regresi yang terbentuk dalam penelitian ini adalah sebesar 0,868596 yang menunjukkan bahwa kemampuan variabel independen yang terdiri dari Kewajiban Penyediaan Modal Minimum (KPMM), Cadangan Kerugian Penurunan Nilai (CKPN), Non Performing Loan Gross (NPL Gross), Net Interest Margin (NIM), Beban Operasional Pendapatan Operasional (BOPO), dan Loan to Deposit Ratio (LDR) dalam menjelaskan variabel dependen (Return 
On Asset) adalah sebesar 86,8596\%, sisanya sebesar 13,1404\% dijelaskan oleh variabel lain seperti inflasi, GDP (Gross Domestic Product), nilai perusahaan, Posisi Devisa Netto (PDN), dan lain-lain.

\section{DAFTAR PUSTAKA}

1. Dendawijaya, Lukman, "Manajemen Perbankan”, Cetakan Kedua, Ghalia Indonesia, Jakarta, 2003.

2. Dendawijaya, Lukman, "Manajemen Perbankan", Edisi Kedua, Ghalia Indonesia, Jakarta, 2009.

3. Dewi, Dhika Rahma, Prasetiono, "Faktor-faktor yang Mempengaruhi Profitabilitas Bank Syariah di Indonesia”, Institutional Repository Universitas Diponegoro, 2011.

4. Edhi Satriyo Wibowo, Muhammad Syaichu, "Analisis Pengaruh Suku Bunga, Inflasi, CAR, BOPO, NPF terhadap Profitabilitas Bank Syariah", Diponegoro Journal of Management, Volume 2, Nomor 2, Hal.1-10, Tahun 2013.

5. Gitman, Lawrence J., "Principles of Management Finance”, Tenth Edition, Pearson Education, Inc, United States, 2003.

6. Halim Abdul, Sarwoko, "Manajemen Keuangan (Dasar-dasar Pembelanjaan Perusahaan Buku 1: Manajemen dan Analisis Aktiva", Cetakan Ketiga, BPFE-Yogyakarta, Yogyakarta, 2008.

7. Kasmir, "Analisis Laporan Keuangan", Rajawali Pers, Jakarta, 2008.

8. Kasmir, "Bank dan Lembaga Keuangan Lainnya”, PT RajaGrafindo Persada, Jakarta, 2008.

9. Koch, Timothy W and S. Scott MacDonald, "Bank Management", 5 Edition, United State : Navta Associates, Inc, 2003.

10. Koch, T. Scott, "Bank Management", Harcourt Inc, Orlando, 2000.

11. Kuncoro, Mudrajad dan Suhardjono, "Manajemen Perbankan Teori dan Aplikasi", Edisi Pertama, BPFE
Universitas Gajah Mada, Yogyakarta, 2001.

12. Listiyani, Ida Nurhayati, Faktor-faktor yang Mempengaruhi Profitabilitas Perbankan, "Students' Journal of Accounting and Banking", Vol. 3, No.1 (2014).

13. Martono, D. Agus Harjito, "Manajemen Keuangan" Cetakan Kedelapan, Ekonisia, Yogyakarta, 2010.

14. Munawir S., "Analisa Laporan Keuangan", Cetakan Ketiga Belas, Liberty, Yogyakarta, 2004.

15. Pedoman Akuntansi Perbankan Indonesia (PAPI), 2008.

16. Peraturan Menteri Keuangan Nomor 76/PMK.05/2008 Tentang Pedoman Akuntansi dan Pelaporan Keuangan Badan Layanan umum.

17. Pernyataan Standar Akuntansi Keuangan Nomor 31 Tentang Akuntansi Perbankan, 1994.

18. Slamet Riyadi, "Banking Assets and Liability Management", Fakultas Ekonomi Universitas Indonesia, Jakarta, 2003.

19. Riyanto, Bambang, "Dasar-Dasar Pembelanjaan perusahaan", Cetakan Ketiga, Gadjah Mada, Yogyakarta, 1975.

20. Riyanto, Bambang, "Dasar-Dasar Pembelanjaan perusahaan", Edisi 4, BPFE, Yogyakarta, 2001.

21. Simangunsong, MP, "Pelajaran Akuntansi Dasar Dua", Cetakan 9, Karya Utama, Jakarta, 1994.

22. Sulaiman, Wahid, "Analisis Regresi Dengan Menggunakan SPSS Contoh dan Pemecahannya", Penerbit Andi, Yogyakarta, 2004.

23. Suliyanto, "Ekonometrika Terapan, Teori dan Aplikasi dengan SPSS", Penerbit Andi, Yogyakarta, 2011.

24. Wijayanti, Langgeng, Imronudin, Faktor-faktor yang Mempengaruhi Profitabilitas Bank, "UMS ETD- $d b$ ", 2017.

25. Zuzana, Fungaeova, Zuzana and Poghosyan, "Determinants of Bank 
Dalimunthe, I.P. et al./ Analisis Faktor-Faktor Yang Mempengaruhi Tingkat Profitabilitas ..... / Vol.4 No. 2 September 2017 pp 105 - 118

Interest Margins in Russia: Does

Bank Ownership Matter?",

Unpublished Paper, Tigran, 2008. 